\title{
LIETUVOS INTERNETO PIRATŲ SUBKULTŪRA SOCIALINIO DALYVAVIMO ASPEKTU: TORRENT TIPO SVETAINĖS ATVEJIS
}

\author{
Darius Rekis, Simona Rekienè \\ Klaipédos universitetas
}

\begin{abstract}
Anotacija
Straipsnyje, taikant naratyvinę tyrimo strategiją, atskleidžiama Lietuvos interneto piratų subkultūra per socialinio dalyvavimo skaitmeninèje erdvejje prizmę. Stengiantis atsiriboti nuo teisinio šios veiklos vertinimo keliami šie esminiai klausimai: kokie socialinio dalyvavimo internete ypatumai, galima veiklos raiška ir nauda potencialiai veikiančiajam. PAGRINDINIAI ŽODŽIAI: interneto piratų subkultūra, socialinis dalyvavimas.
\end{abstract}

\begin{abstract}
In the article internet pirate subculture of Lithuania will be revealed through social participation in the digital space prism using narrative strategy. In order to distance from the legal assessment of the performance there are raised the main research questions: what are the peculiarities of social participation in the internet subculture, operational expression and the potential benefit for the participator.

KEYWORDS: internet pirates' subculture, social participation.
\end{abstract}

\section{Ivadas}

Niekam ne naujiena, kad internetas ir naujos technologijos bei jų suteikiamos galimybès veikia šiuolaikinę visuomenę. Tik interneto dèka šiandien galime kalbèti apie globalų, kaip ir pats internetas, interneto piratų subkultūros reiškinį, kuris tapo mokslininkų įvairių tyrimų objektu. Interneto piratais laikomi autorinių teisių pažeidejai, kurie savo veiklą grindžia laisvos prieigos prie bet kokios informacijos filosofija, t. y. patys paprastai savo veiklos nusikalstama veika nelaiko arba ją teisina pinigų stoka (Holt, Copes, 2010). Autorinių kūrinių kopijavimas ir platinimas be autoriaus žinios laikomas nusikaltimu, prilygintu vagystei, iš čia kildinamas ir šios interneto subkultūros pavadinimas piratai. Dèl šios specifikos visi subkultūros dalyviai slepia savo asmenybes po ịvairiais išgalvotais vardais net ir bendraudami tarpusavyje. Vyriausybèms ieškant būdų kažkaip sukontroliuoti interneto piratų veiklą natūraliai išprovokuoti ịvairūs pasipriešinimo judèjimai, pasisakantys už prieigos laisvę prie informacijos. Draudimų priešininkų teigimu, uždraudus ,piratavimą“ būtų pažeista žmogaus teisè ị informaciją, žinias, informacijos savininkams tektų filtruoti srautus, drausti prieigas prie nelegalios informacijos, taip internetas prarastų savo kaip laisvo, visą susiejančio tinklo, beribės 
informacijos ir žinių šaltinio funkciją. Europoje net pradejjo kurtis piratų partijos, kurios siekia reformuoti norminius autorių teisių, patentų, istatymų, atvirų šaltinių ir kitų komunikacijos priemonių dokumentus, Švedijoje 2012 m. oficialiai pripažinta nauja, minètas idèjas atitinkanti Kopimismo religija (Sinnreich, 2016). Žinomi trys tarptautiniai piratų partijų susivienijimai: Pirate Parties International, Pirates without Borders, Parti Pirate Francophone. Šiandien tai ne tik Europos ar Jungtinių Amerikos Valstijų visuomenių reiškinys. Atviros visuomenès ideologija, jos raida, naujos tapatybès ir stiliai formuojasi visur, kur tik pabunda subkultūriškumas, kur reiškiasi programavimo ir naujos komunikacijos ịgūdžiai, iš pradžių nedidelès, o galiausiai intensyvios socialinès ar kultūrinès asmens metamorfozès (Mažeikis, 2013). Todèl Lietuva šiuo aspektu nèra jokia išimtis. Interneto piratu subkultūra neturi sienų, jos neriboja valstybès. Nors esama ir mažesnių grupių, šiai subkultūrai prilyginamų darinių, kurie gali būti ir lokalesni, savo veikla atitinkantys tam tikros šalies internautu informacijos poreikius dèl kalbos barjerų.

Torrentai - technologinè atviros informacinès visuomenès priemonè, kitaip dalinimosi failais programa. Torrentu svetainès yra viena iš interneto piratų subkultūros pavyzdžių, jos turi tam tikrą organizacinę struktūrą, kuri palaiko svetainès funkcionavimą, ir vartotojus, kurie per svetainę siunčiasi ir platina įvairius failus. Populiariausios tarp Lietuvos internautu yra šios svetainės: torrent.ai; filmai.in; linkomanija.net ir kt. Kadangi dar $2012 \mathrm{~m}$. Europos Sajungos narès (tarp jų ir Lietuva) pasirašè „Anti-Counterfeiting Trade Agreement“ (ACTA) sutarti, kuri reglamentuoja, kad bus galima sekti interneto vartotojus, atskleisti privačius duomenis be teismo sprendimo, filtruoti paslaugų tiekejjų informacijos srautą, skirti papildomas bausmes, įskaitant atjungimą nuo interneto, tiek šiu svetainių vartotojai, tiek aktyvūs piratinès produkcijos platintojai stengiasi likti neidentifikuoti. Dėl šios priežasties aktualus ir įdomus moksliniams tyrimams objektas - interneto piratu subkultūra - sunkiai pasiduoda ịprastiems tyrimų metodams, todèl Lietuvoje jis vis dar lieka beveik netyrinètas.

Interneto, kaip atviros informacijos dalijimosi platformos, atsiradimas ne tik keičia visuomenès komunikavimo įpročius, bet ir formuoja naujas socialinio dalyvavimo raiškos galimybes. Dalyvavimą skaitmeninëje erdvèje C. Kelty, A. Panofsky ir kt. (2015) įvardija kaip šiuolaikinį, tačiau jo nesiūlo kažkaip išskirti analizuojant kaip naują dalyvavimo visuomenèje rūšį, nes skiriasi tik asmens veiklos terpè, todèl mokslininkai siūlo šiuolaikinị dalyvavimą interneto erdvẻje analizuoti taikant ịprastus socialinio dalyvavimo reiškinị apibrěžiančius kriterijus. Socialinis dalyvavimas nèra naujas visuomenès reiškinys, kuris tyrinejamas Lietuvoje tiek integracijos bendruomenejje (Ruškus, 2007), tiek edukacijos (Rekis, 2014) ar kt. aspektais, bet kuriuo atveju dalyvauti visų pirma reiškia būti vyksmo dalimi, sąmoningai veikti, tapatinant veiklą su savo ketinimais (Cymru, 2000). Socialinis 
dalyvavimas - tai asmens aktyvumas atviroje bendruomeneje, neformaliai jai įsipareigojant dèl abipusès naudos, kuri materialiai neapčiuopiama, pasireiškiantis asmens vidinių savybių, lemiančių potencialias jo galimybes, ir išorinių veiksnių itakos kontekste (Rekis, 2014). Asmens nauda socialinio dalyvavimo aspektu suvokiama kaip socialinio dalyvavimo igijiniai, t. y. per patirti veikloje igytu socialiniu kapitalu, žiniomis, ịgūdžiais, saviugda, individo teigiamų asmeninių savybių lavinimu, savirealizacija ir t. t. Asmens veiklos nauda (nebūtinai suvokta) yra vienas pagrindinių motyvuojančių veikti veiksnių, todẻl analizuojant tyrimo duomenis vadovaujamasi šia prielaida siekiant identifikuoti galimus asmens socialinio dalyvavimo interneto piratų subkultūroje ịgijinius.

\section{Tyrimo strategija}

Tyrimo objekto (Lietuvos interneto piratų torrent svetainès bendruomenès subkultūra) specifika paskatino pasitelkti Lietuvoje rečiau taikomą naratyvinę tyrimo strategiją - tai viena iš kokybinių tyrimų strategijų. Naratyvas - tai asmens patirties pasakojimas, viso ar dalies gyvenimo istorija. I. Goodson ir R. S. Gill (2011) skiria pagrindinį naratyvų privalumą - patirčių individualizavimą ir konkretizavimą. Jie pabrezžia tris bendrus naratyvų požymius: laikinumas - visi pasakojimai apima ịvykių seką; prasme - asmeninės reikšmės ir prasmès yra eksternalizuojamos, pasakojant patirtis; socialinis susidūrimas - pasakojimai yra papasakoti viešai, todèl neišvengiamai reikšmès bus formuojamos pasakotojo ir klausytojo santykyje. I. Goodson (2013) teigimu, naratyvinès analizès tradicija tyrimuose remiasi prielaida, kad istorijos pasakojimas ir patyrimas yra neatskiriami. Patyrimas vèl tampa prieinamu, kai jis virsta pasakojimu (naratyvu), turinčiu savo planą, kuriam žmogus suteikia tam tikrą prasmę ir ị kuri patalpina save, nors pagrindinis veikèjas jo pasakojime gali būti ir kitas. J. W. Creswell (2007) pastebi, kad naratyvinio tyrimo metodas prasideda asmens pasakojimu apie tai, kaip jo patirtis pasireiškè ir buvo išgyventa, o procedūros, ịgyvendinant šį tyrimą susideda iš to, jog daugiausia dèmesio skiriama vienam ar dviem asmenims, renkant, registruojant asmens istorijas ir patirtis bei jas chronologiškai pateikiant. Kaip ir daugelis kokybinių tyrimų naratyvas kritikuotinas dèl tyrimo duomenų subjektyvumo, tačiau būtent toks tyrimo metodas leidžia giliau pažvelgti ị tyrimo objektus. Pasak I. Goodson ir S. R. Gill (2011), vertinant naratyvinị tyrimą dèmesį reikètų skirti tam, kaip prasmingai ir išsamiai tyrèjas sugebejo atskleisti individų patirtis, taip pat vertinti, ar tyrèjas gerai sugebėjo ižzvelgti pasakojimo siužetą ir kaip jam pavyko išskirti pagrindines pasakojimo temas. Jeigu tyrejas gerai tai atliko, tyrimas pasižymi validumu, tuo tarpu, ar tiriamųu patirtys reprezentuoja platesnès socialinès grupès patirtis, ne tiek svarbu. 


\section{Duomenų analizė}

Analizuojant tyrimo duomenis jie buvo suskaidyti ieškant bendrų tematikų ir siekiant išdèstyti pasakojimo įvykius chronologine tvarka, išskiriant: pradžią, kaip asmens ịsitraukimo ị torrent svetainès bendruomenę prielaidas ir ịvykius, veiksnius, motyvus, kurie tai lèmè, bei veikla bendruomeneje, atskirai analizuojant asmens motyvaciją veikti ir pačios bendruomenès specifiką, kaip , pavyzdžiui, vidaus tvarką, taisykles, bendravimo kultūrą ar moralines nuostatas ir t. t.

Informanto pasakojimas atskleide, kad prisijungti prie torrent svetainès bendruomenès interneto piratų subkultūroje nesudètinga. Čia dažniausia visi bendrauja pasivadinę slapyvardžiais, pirmas žingsnis - ,laisva registracija“ svetainėje susikuriant savo anketą, profili su savo prisijungimo duomenimis ir tampant svetainès vartotoju - pasyviuoju interneto piratų bendruomenès nariu, kuris siunčiasi failus naudodamasis svetainès sistemoje įdiegta torrent dalijimosi failais programa. Apie pasyviuosius interneto piratų subkultūros veikejjus nemažai rašoma ir diskutuojama autorinių teisių kontekste, tačiau aktyvūs piratai Lietuvos autorių beveik netyrinèti. Teoriniu lygmeniu šios subkultūros veikimo filosofiją ir būdus bando paaiškinti G. Mažeikis (2013), jis ir išskiria pasyvius bei aktyvius piratų subkultūros veikejjus. Šiame straipsnyje nagrinejjama aktyvioji interneto piratų subkultūrai priklausanti asmenų dalis ir jos, kaip bendruomenès, veikimas.

Isitraukimas: Büdavo laisva registracija ir paskui su pakvietimais. Kad žmogus būtu aktyvus mūsu grupès narys reikèjo... nežinau, tiesiog, būti normaliu. Norèti kažka padaryti, padèti, išmokti. Šiaip bendraudavo ir susibendraudavo.

Vertindami tyrimo duomenis, galime teigti, kad aktyvaus ịsitraukimo ị bendruomenę pagrindinis veiksnys - pirmiausia paties asmens motyvas, noras veikti, priklausyti tokiai bendruomenei. Be to, reikia pastebèti, kad noro gali neužtekti, jei individas neras bendros kalbos su likusiais ar bent jau itakingiausiais bendruomenès nariais. Asmuo turi pritapti bendruomenejje veikdamas savanorystès pagrindais, t. y. jo niekas atskirai tarsi nemotyvuoja. Kita vertus, informanto pasakojime galime ịžvelgti ir prisijungusių pasyviujų svetainès vartotojų, narių, motyvacijos pastiprinimo elementų. Todèl reikètų ịvertinti tai, kad motyvacija ịsitraukti būtina pirminejje stadijoje, kai neretai kadrai, nauji nariai verbuojami tiesiog bendraujant.

Prisijungimo motyvai: a) filmai: ...tiesiog ieškojau, kur filmu parsisiųsti (...) Atsimenu, kad atejjau atsisiųsti kažkokio torrento ị viena puslapi (...) vis kai užsukdavau kažko parsisiusti, vis su kažkuo ten pasikalbédavau; b) bendravimas: ...ir ten seniau büdavo tokia vadinama „Šaukykla“ - pokalbiu langelis, kur galédavo visi 
nariai susirašinèti. Lyg ir buvo neseniai krepšinio varžybos pasibaigusios ar kažkas tokio, kad ten visi turejo apie ka pasikalbèti. I ta pokalbị kažkaip ir aš ịsitraukiau, nes tuo metu labai krepšiniu domëjausi. (...) visi linksmai pasikalbejjom. (...) ten buvo toks pokalbiu langelis, kur visi bendravo. Kaip tik buvo vasara, neturejjau kq veikti, taip ir prisijungiau i pokalbị. (...) patraukè turbūt tai, kad ten jaunimas kalbedavo (...) Taip susipažinau su to puslapio nariais ir įsitraukiau.

Pirminis praktinis motyvas „,parsisiųsti filmą“, taip iš dalies įsitraukiant ị interneto piratų bendruomenès veiklą, nors ir tampant tik pasyviu šios bendruomenès nariu, ilgainiui gali tapti pagrindine prielaida aktyviai įsitraukti į bendruomenès veiklą, jei užmezgamas ryšys su aktyviais svetainès vartotojais ir jos administratoriais. Tam tokiose svetainėse sudarytos galimybès sukuriant bendravimui skirtą platformą. T. J. Holt ir H. Copes (2010), nagrinėdami interneto piratų subkultūrą kaip deviantinị elgesį, taip pat pastebejjo, kad piratų bendruomenę palaiko „,bendraminčiai“, t. y. prisijungia tie, kurie pritaria tokiai veiklai ir bendruomenès kultūrai, o aktyvūs bendruomenès nariai nevengia diskutuoti ir interneto erdvèje puoselèti savo kultūrą, taip pritraukdami vis naujus narius.

Jei kalbėsime apie tiriamos bendruomenès populiaciją, tai tyrimo duomenys atskleidžia, kad internetas leidžia ị bendruomenę susiburti įvairaus amžiaus žmonèms iš įvairiausių vietovių, kur tik yra internetas.

Populiacijos ivvairovè: ...ten visi būdavo iš labai skirtingu miestu (...) Nes ten „,ateidavo“ "ne tik jaunu, bet ir žmoniu, kuriems ir 30, 40, 50 metų.

Kadangi internetas sudaro galimybę veikti inkognito, sunku iškarto nustatyti, su kuo bendraujama. Sužinojus, kad internautų bendruomenejje amžiaus prasme aktyviai veikia ir trisdešimtmečiai ar penkiasdešimtmečiai, kyla klausimas, kiek tai saugu, ar ne vyresnieji inicijuoja tokias bendruomenes pasipelnymo tikslais išnaudodami entuziastingą jaunimą? Tačiau tyrimo duomenys atskleidžia, kad šių bendruomenių iniciatoriai ir pagrindiniai veikèjai visgi yra jauni žmonės, neretai net nepilnamečiai, kurie dažniausia yra ịvaldę kompiuterines technologijas geriau nei vyresnieji.

Amžius: Prisijungiau dar būdama moksleivè (...) Manau, kad 17 metu. Gerai sutariau su to puslapio savininku, jam tuo metu buvo tiek pat metu, tai jis man papasakodavo, kaip čia šitas dalykas sukasi...

Analizuojant duomenis išskirta interneto piratų (aktyvių) torrent svetainės bendruomenès veiklos ir torrent bendruomenès kategorijos, kad naratyvu gauti duo- 
menys padètų bent iš dalies atskleisti šios subkultūros veiklos ir tarpusavio bendravimo subtilybes. Analizuodamas interneto piratų subkultūrą M. Choi (2016) ją aptaria kaip socialinio dalyvavimo skaitmeninejje erdvejje reiškini ir identifikuoja keturias skaitmeninès pilietybės kategorijas: 1. „Etika internete“, kuri reiškia atsakingą elgesị internete. 2. „Medijos ir informacinis raštingumas“ susiję su interneto prieiga ir techniniais bei psichologiniais gebėjimais naudojant internetą sẻkmingai bendrauti su kitais internete. 3. „Dalyvavimas / İsitraukimas“ reiškia politinį, ekonominị ir kultūrinị dalyvavimą esamose socialinèse struktūrose. 4. Kritiškumas reiškia daugiau kritinio dalyvavimo ginčijant status quo ir skatinant socialinị teisingumą internete. Nors išskiriamos keturios kategorijos atitinka tam tikras savybes, jos ne visada išskiriamos lyginant su kitomis kategorijomis, nes skaitmeninis pilietiškumas, anot M. Choi (2016), paprastai diferencijuoja tarp šių kategorijų. Lietuvoje skaitmeninio pilietiškumo reiškini aptaria G. Mažeikis (2013), daugiau dèmesio skirdamas interneto, kaip laisvai prieinamos informacinès erdvès, idejos puoselètojams ir jų veikimo internete formoms. Torrent svetainès atitinka šios idèjos dvasią, nors labiausiai yra kritikuojamos dèl autorinių teisių pažeidimų, tačiau interneto piratai neigia autorines teises kaip ir bet kokị kitą galimą prieigos prie informacijos internete ribojimą.

Analizuojant tyrimo duomenis paaiškejjo, kad motyvai veikti tokioje bendruomenėje nebūtinai turi kažkokias pilietiškumo, kovos už laisvę, pasipriešinimo sistemai apraiškas. Lietuvos internautus motyvuoja paprastesni veiksniai, tokie kaip: bendravimas, užsimezgusi draugystė ar tarpasmeniniai santykiai, neretai ir finansine nauda, tam tikras laisvalaikio leidimo būdas ir t. t. Asmens motyvacija veikti atskleidžia ir naudą, kurią gauna ar mano gaunantis internautas, aktyviai ịsitraukdamas ị interneto piratų subkultūros veiklas, tai padeda identifikuoti galimus asmens socialinio dalyvavimo interneto piratų subkultūroje ịgijinius. Kitaip tariant siekiama nustatyti, ką šioje veikloje edukaciniu ar socialiniu požiūriu naudingo gali igyti internautas.

Veikla. Motyvacija veikti. A1) Bendravimas. Daugiausiai kalbėdavau (...) Daugiausia tai plepèjimas (...) Iš pradžiu dangiau bendruose pokalbiuose, kur bet kas galèdavo matyti ir prisijungti ị pokalbi, o paskui kažkas sukūrè Skype pokalbio konferencija, tai ten visi susirašinedavom. Ilgiausia taip ir bendravom, Skype. Jau ta visa moderatoriu komanda tarpusavyje. Apie tuos administracinius reikalus šiaip gal 10 proc. laiko tik kalbédavom, visus kitus 90 proc. kalbédavom, kas šaudavo i galva, juokaudavom ir pan. Vasaromis iki paryčiu prasikalbédavom. Ten daug žmoniu būdavo vienam pokalby, gal 10. Patys kažkaip jau paskui ten nelabai bendravom, bet būdavo smagu matyti, kiek susipažista kiti vieni su kitais ir smagiai bendrauja. (...) būdavo organizuojami vadinami meet'ai (susitikimai), tik aš 
juose nebuvau. İdomi patirtis, pažintys. Darème, nes turbūt patiko. Ne pats ,,darbas", kiek tas bendravimas su žmonèmis. Ten žmonès ne tik on line (prisijunge internetu) būdavo pažistami, bet ir susitikdavo gyvai, organizuodavo susitikimus.

Vertinant tyrimo duomenis būtų galima teigti, kad tarpusavio bendravimas yra vienas pagrindinių ị tokią veiklą ịtraukiančių ir joje palaikančių motyvacijos veiksnių. Nors V. Pruskus (2013) teigia, kad internetinès kultūros puoselejjami informacijos gavimo ir perdavimo būdai žmonių bendravimą nuskurdina, neugdo tiesioginio bendravimo ịūdžių, patị bendravimą formalizuoja, įspraudžia jị ị interneto techninių raiškos galimybių diktuojamus rèmus, tačiau būtent bendravimas interneto erdveje yra vienas labiausiai motyvuojančiu veiksnių burtis ị skaitmeninejje erdvejje veikiančias subkultūros bendruomenes. Tai galima būtų paaiškinti dèl naujų technologijų poveikio pakitusiais bendravimo ịpročiais, tačiau poreikis bendrauti niekur nedingo.

A2) Draugystè. Kai esi tame, kažkaip prisijaukini tuos žmones ir jie tokie kaip draugai tampa (...) ten visi buvo labai draugiški, tai kai viena karta pritrūko pinigu susimokèti už serverị savininkams, nes jie tuo metu jauni buvo, irgi moksleiviai, tai tie aktyviausi bendruomenés nariai susimetè ir padejo sumokèti, kad tik tas puslapis išliktu. Draugu...

A3) Santykiai. Oi ten būdavo ir meilès istoriju (...) Žinau gal kokias 5 poras, kur žmonès tame puslapyje susipažine paskui tapo pora realiam gyvenime. Aš su savo pačios vyru susipažinau tame puslapyje (...) mes gal pora metu taip virtualiai buvom pažistami, kol susitikom iš tikrujų. Ir susitikom, jau 4 metus kartu gyvenam. Ir ne tik man vienai, yra tikrai taip susipažinusiu, irgi iki šiol gyvena. O kiek dar aš nežinau. Ne iš mano draugu rato kiek buvo. (...) susipažino vyras su tokia moterimi per ta puslapi, išsiskyrè su savo žmona ir dabar jie laimingai gyvena. (...) daug porų kažkaip ten susidaré.

Tyrimo duomenys atskleidè ir tai, kad torrent svetainès bendruomeneje bendravimas, tarpusavio santykiai turi didžiulę svarbą šios bendruomenės egzistavimui, o komunikacija tarp bendruomenès narių neapsiriboja tik skaitmenine erdve. Veikimas tokioje bendruomeneje sudaro galimybes formuoti tam tikrą socialinị kapitalą, užmegzti pažintis, kurios ateityje gali virsti draugyste ar net labai artimais tarpusavio santykiais.

Analizuodamas kitus aktyvios veiklos torrent svetainių bendruomeneje motyvus informantas pripažino, kad egzistuoja ir finansinès naudos galimybė tam tikrai 
veiklos kategorijai - filmų garsintojams. Be to, svetainių savininkai gauna pajamų už reklamą ir pan.

Veikla. Motyvacija veikti. B) Finansinè nauda. ...jis (informantès vyras) iš to mano draugo nupirko visa ta puslapi ir tapo jo savininku, ten talpindavo reklamas ir už tai gaudavo pinigus, toks buvo jo verslas. Kituose puslapiuose tikrai žinau, kad igarsintojams mokedavo.

Tačiau finansinè nauda motyvuoja tik nedidelę tokios bendruomenès dalị. Kitus, be galimybès bendrauti, motyvuoja pripažinimas bendruomenejje ar tiesiog veiklos įdomumas.

Veikla. Motyvacija veikti. C) Pripažinimas. Na, jei sukiesi torrent pasaulyje, vien tas statuso suteikimas (administratoriaus statuso) yra garbè ir pripažinimas. Gal pats tas toks buvimas valdžioje, kitiems labai patikdavo kažkam pavadovauti, kažka išmokyti. D) Interesas. Ne, nieko (nemokédavo), tiesiog man pačiai būdavo idomu tai daryti, man patikdavo tokia veikla.

Edukaciniu aspektu labai svarbus saviugdos veiksnys, kuris čia taip pat gana ryškus. T. J. Holt ir H. Copes (2010), tirdami interneto piratų subkultūrą kaip delinkventinị reiškini, pastebejo, kad šiose bendruomenèse saviugda vaidina svarbų vaidmenį, nes, jų teigimu, interneto piratų igūdžiai ir žinios apie piratavimą išsivysto praktikoje ir, galbūt dar svarbiau, sąveikaujant su kitais piratais. Igūdžių, kurie būtini, siekiant veikti tokioje subkultūroje, niekur kitur neigysi, tik bendraudamas ir veikdamas joje, todèl galima teigti, kad tokios bendruomenès yra ir neformalaus ugdymo(si) terpé, kurioje, kaip atskleidè tyrimo duomenys, igyjamos nebūtinai delinkventinio pobūdžio žinios ir gebejimai.

Veikla. Motyvacija veikti. E) Saviugda. Tai jis su draugu, kai nupirko ta puslapi, nieko apie torrentus nemokejo, nežinojo, kas ten per komanda, ka ji daro ir pan. (...) viska paaiškinau, kaip čia kas. Išmokau paaiškinti ta pati dalyka 100 kartu per diena daugeliui skirtingy asmenu ir neišprotèti. Kaip suburti komanda, ja išlaikyti. Kaip bendrauti, kad žmonès norètu būti tavo komandos dalimi, ka ir kaip pasakyti / paprašyti. Apskritai bendravimo su žmonèmis. Nes ten naujokams dažnai reikédavo pagalbos, kaip naudotis puslapiu. Nežinodavo, kas tie torrentai, kaip čia siustis. Palaipsniui taip viskas ir išsirutuliojo, kuo daugiau ten dalyvavau, tuo daugiau sužinojau. Išmokau administruoti puslapius, susigaudau šiek tiek puslapiu redagavime, tiek ir dave... 
Edukacija veikiant bendruomeneje suteikia ịvairių socialinio dalyvavimo ịgijinių, kuriuos derètų plačiau išanalizuoti neturint pirmalaikès neigiamos nuostatos dèl tokių bendruomenių. Ar tokia veikla, kaip torrent svetainių, visada pasižymi internetiniu pilietiškumu, apie kurị kalba M. Choi (2016)? Vertinant tyrimo duomenis tenka tuo suabejoti, tačiau T. J. Holt ir H. Copes (2010) požiūriu ị interneto piratus tik kaip ị deviantinio elgesio internetinèje erdvejje apraišką taip pat nebūtų galima vadovautis. Nors internetas neturi sienų, ịvairūs judẻjimai, idejos plinta visame pasaulyje surasdami šalininkų, tačiau egzistuoja ir mažesnès internautu bendruomenès, kaip mūsų tyrimo atveju, kurių kultūrai, galime daryti prielaidą, įtakos turi tos šalies, kurios erdveje veikia šios bendruomenès nariai, kultūra ir tradicijos. Pateikus šias įžvalgas ir socialinio dalyvavimo apibrěžti, kad tai yra vyksmas bendruomenèje, tikslinga bent pabandyti atskleisti interneto piratų subkultūros subtilybes.

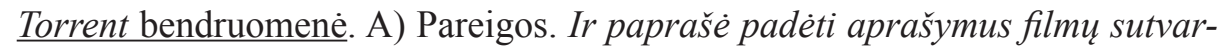
kyti, taip ir sutikau. (...) filmy aš visai neigarsindavau, aš tik ieškodavau žmoniu, kurie galètu juos igarsinti. Daugiausia tai būdavo puslapio administravimas - nauju „moderatoriu“ “ paieška, torrentu aprašymu pildymas, puslapio forumo priežiūra. Ten būdavo toks vadinamasis „,template“ - puslapio variklis, gal dar dabar yra, vadinasi TS-TemplateShares, kur nusiperki ta visa ,, interfeisa “, talpini jame savo turini ir ji administruoji. Ten būdavo daug tu pavadinimų: vertejjai ir igarsintojai vadinosi „DLK komanda“, o mes tai tiesiog adminai, moderatoriai. Buvo DLK vyriausiasis (tai aš ), kuris jau ten kiečiausias, o prie savininku nick'u (slapyvardžiu) taip ir büdavo parašyta, kad ,,Savininkas“. Forumo moderatoriai, torrentu moderatoriai.

Vertinant tyrimo duomenis matyti, kad aktyvioji torrent bendruomenė yra susiskirsčiusi pagal bendruomenejje atliekamas funkcijas, kurios siejamos su torrent interneto svetainès administravimu ir palaikymu. Mums pavyko identifikuoti šias bendruomenès grupes: savininkai (svetainès savininkai, hierarchine prasme tai aukščiausias, svarbiausias grupès narių statusas); administratoriai (savanoriškais pagrindais veikiantys ir pasitikejimą ịiję svetainès administratoriai, kuriems suteikiamos dalinès svetainès administravimo prieigos); vertèjai ir igarsintojai (tie, kurie išverčia ir ịgarsina nelegalius filmus, jiems už šị darbą neretai atlyginama finansiškai). Tai pagrindinès torrent bendruomenès grupès, prie kurių būtų galima priskirti pasyviuosius, kaip svetainès vartotojai ir potencialūs nauji bendruomenès nariai. Iš to bendruomenės narių pareigų ir funkcijų galime numanyti, kokių ịgūdžių ir žinių neformaliu būdu potencialiai gali iggti bendruomenès nariai (vertimas, igarsinimas, administravimas ir t. t.), todèl torrent internautų bendruomenè galétų 
būti įdomi tyrimams ir edukaciniu aspektu išsamiau nagrinèjant saviugdos galimybes šioje terpèje. Tačiau tirdami ši reiškinį edukaciniu aspektu galime susidurti su tyrimo etikos dalykais, nes tokių bendruomenių veikla autorių teisių kontekste yra nelegali ir neteisèta. Koks pačių internautų požiūris ị jų veiklos teisètumą?

Torrent bendruomenè. B) Teisètumas. Tas puslapis jau nebeegzistuoja, mes ji uždarèm, nes gavom kvietima i p policija. O kad neteisèta buvo, tai visi žinojome, bet kažkaip apie tai negalvodavom ir nebūdavo tas svarbu. Apie tai visai nekalbèdavom. (...) policija tikrai pas mus nesibraudavo, jiems rüpèjo Linkomanija, torrent. lt (dar tuo metu toks psl. buvo), dabar jau man atrodo kitoks adresas. Esam užblokavę kelis vartotojus su emailu (elektroninis paštas), kuris baigiasi@policija.lt

Tyrimo duomenimis, dèl veiklos teisètumo interneto piratai nesuka sau galvos. Lietuvoje nèra teisminès praktikos, kuri leistų bausti tokių bendruomenių vartotojus, nes įrodyti nusikaltimą sudètinga. Kita vertus, tikriausiai mūsų pareigūnai, bandydami juos susekti, yra prasčiau įgudę naudotis naujausiomis technologijomis, nes kaip kitaip paaiškinti registraciją tokiose svetainėse naudojant tarnybinį elektronini paštą? Viena aišku, kad interneto piratų subkultūrai priklausantys asmenys dèl savo veiklos teisètumo nesijaudina, priima tai kaip savaime suprantamą dalyką ir net nekelia tokių klausimų bendruose pokalbiuose. Nors veiklos teisètumas jų nejaudina, bendruomenejje svarbų vaidmenį vaidina pasitikejjimo veiksnys, kuris ir motyvuoja veikti, be kurio veikti bendruomenëje negalètu joks jos narys.

Torrent bendruomenè. C) Pasitikejjimas. Tai, kai jau tavimi pasitiki ir padaro „,moderatoriumi “, suteikia tau teises valdyti ta puslapi. Kiekvienam gali priskirti skirtingus dalykus, pagal pasitikejjimo laipsnị. Šiaip filtruodavom tuos, kurie nori patekti i administracija ar DLK komanda, na ten, kur gali patekti ị puslapio vidu. Ten turèdavo büti jau garbę užsitarnavęs pilietis.

Socialinio dalyvavimo aspektu nustatytas svarbus bendruomenès veikimo ir palaikymo veiksnys - savanoriškumas, nes daugeliui veikla bendruomenejje neatneša jokios finansinès naudos. Bendruomenès savanorystè, kiek ši sąvoka vartotina šiuo atveju, siekiant palaikyti ir išsaugoti torrent svetainès veiklą dèl šios veiklos neteisètumo gali kelti abejonių, tačiau tikra yra tai, kad bendruomenès nariai savo noru, neatlygintinai veikia bendruomenès labui, o tai atitinka savanorystės apibrěžimui keliamus reikalavimus. 
Torrent bendruomenè. D) Savanoriškumas. ...tiems administratoriams tai ne, tai büdavo savanoriška veikla, kiek kas nori ir kas gali. Ir iki šiol nei Linkomanijoj, nei kituose torrent puslapiuose už administravima niekas nemoka.

Dar vienas labai ịdomus internautų bendruomenès nustatytas aspektas - jie savo veiklą traktuoja ne tik kaip savanorystę, bet ir kaip laisvalaikị. Tai leidžia naujos technologijos, kurios vis labiau tampa neatskiriama visuomenès dalimi.

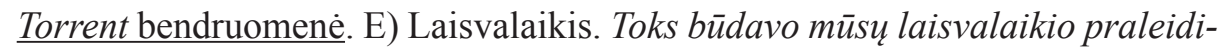
mo būdas savaitgaliais, po mokyklos. Čia labiau toks laisvalaikio praleidimo būdas. Kažkaip linksmai prisimenu ta laika. Dabar juokinga kažkaip prisiminus, bet nesigailiu, ịdomūs laikai buvo. (...) šiaip linksmai plepèdavo, tai toks laisvalaikio praleidimo büdas gaudavosi. (...) tiesiog buvo kaip hobis.

Atrodytų interneto subkultūrai priskiriami asmenys turètų būti tolerantiški ir siekti bendradarbiauti, kovojant dèl tų pačių idejjų ir vertybių, tačiau, remiantis tyrimo duomenimis, būtent torrent svetainių bendruomenès tarpusavyje konkuruoja ar net stengiasi viena kitai pakenkti.

Torrent bendruomene. F) Bendruomenių konkurencija. ...konkuruodavom su kitais panašaus lankomumo puslapiais, pas ka bus geriau ir pan. (...) būdavo, kad ateidavo iš kitu puslapiu specialiai pakenkti, iš pavydo. (...) tada būdavo labai svarbu, kas naujausia filma i kels pirmas, konkurentai ar mes. Dèl konkurencijos, tai ji būdavo, nelabai bendradarbiaudavom. Tarp konkurentu santykiai, manau, niekada nera geri.

Konkurenciją tarp tokio tipo bendruomeniu gali paskatinti pelno siekis, kuris, kad ir nedidelei daliai bendruomenès narių, vis dèlto egzistuoja kaip vienas iš veiklą motyvuojančių veiksnių. Finansinè nauda iš tokių interneto svetainių aštrina ir interneto pilietiškumo, savanorystės bei legalumo, autorių teisių klausimus. Galima būtų kelti klausimą, ar internautai neišnaudojami pavienių asmenų, siekiančių tik finansinès naudos? Tai galètų būti tolesnių tyrimų erdvè, nes akivaizdu, kad interneto piratų subkultūra yra sudètinga bei ịvairiapusè, todèl bus tiriama ir ateityje.

\section{Diskusija}

Tiriant Lietuvos internautų, interneto piratų subkultūrą socialinio dalyvavimo aspektu paaiškejjo, kad ši bendruomenè, nors ir turi tam tikrą specifiką, visgi veikia kaip bendruomenè, kurioje veikia visi bendruomenei būdingi veiksniai, pa- 
vyzdžiui, ị savo veiklą aktyviai integruoja šiuolaikines technologijas. Tenka pritarti C. Kelty, A. Panofsky (2015) ir kitiems mokslininkams, kurie dalyvavimą skaitmeninèje erdvejje įvardija kaip šiuolaikinį, tačiau jo nesiūlo kažkaip išskirti analizuojant jị kaip naują dalyvavimo visuomenejje rūši. Tiesa, socialinis dalyvavimas skaitmeninejje erdvejje kelia nemažai klausimų tiek dẻl internautų veiklos teisètumo, tiek dèl moralumo, tačiau veikimo bendruomenèje principai išlieka - jei ne tokie pat, tai labai panašūs. Tik nedidelei bendruomenès daliai ši veikla teikia finansinę naudą ir šiuo aspektu ji tarsi iškrenta iš socialinio dalyvavimo, lieka už jo, tačiau šie asmenys tampa pagrindiniai tų platformų, apie kurias vẻliau susiburia internautų bendruomene, veikianti savanorystès pagrindais, kūrejai. Galima kelti klausimą, ar tai nėra kitų išnaudojimas siekiant asmeninès naudos? Sunku pasakyti, išsamiau neištyrus, kaip naudojamos šioje veikloje gautos lěšos, tačiau tokia prielaida tikrai egzistuoja ir ji internautų socialinio dalyvavimo nepuošia, suteikia tam neigiamą atspalvị.

Nors tyrimo duomenys negali būti vertinami vienareikšmiai, tačiau jie leido pažvelgti ị mažai Lietuvoje tyrinètą sriț kitu aspektu, t. y. ne tik kaip į nusikalstamą veiklą, bet ir kaip ị tam tikrą socialini dalyvavimą. Tyrimo duomenys leido nustatyti, kad ịsitraukimas ị interneto piratų bendruomenę nèra sudètingas ar labai kriminalizuotas, dažniausiai tai tiesiog šiuolaikinio jaunimo aktyvaus veikimo forma, kuri keičia ịprastą bendravimą ir dalyvavimą bendruomenių veiklose. Torrent svetainių bendruomenès veikia kaip mums jau ịprastos nevyriausybinès organizacijos ir, jei ne autorių teisių klausimas, tikriausiai nekiltų klausimo, tai gerai ar blogai. Akivaizdu, kad aktyviai veikdami bendruomeneje, kad ir naudojant technologijas, jos nariai igyja tam tikrų kompetencijų, plečia socialinị kapitalą, komunikuoja ir socializuojasi kaip ir bet kurioje kitoje bendruomenejje. Atlikus tyrimą nesiekiama teigti vienos tiesos, tik viliamasi, kad šie duomenys inspiruos tolesnius interneto piratų subkultūros tyrinèjimus Lietuvoje.

Gauta 20161103

Pasirašyta spaudai 20161203

\section{Literatūra}

Cymru, C. (2000). Tarp žmonių: parankinè socialinio darbuotojo knyga. Vilnius: Apyaušris.

Choi, M. (2016). A Concept Analysis of Digital Citizenship for Democratic Citizenship Education in the Internet Age. Theory \& Research in Social Education, No. 44, p. 565-607.

Creswell, J. W. (2007). Qualitative inquiry and research design: Choosing among five approaches. Thousand Oaks, CA: Sage.

Goodson, I. (2013). Developing narrative theory: Life Histories and Personal Representation. Routledge. Canada: Routledge.

Goodson, I., Gill, S. R. (2011). Narrative Pedagogy. Learning from Life History. Routledge. New York: Peter Lang Publishing. 
Holt, T. J., Copes, H. (2010). Transferring Subcultural Knowledge On-Line: Practices and Beliefs of Persistent Digital Pirates. Deviant Behavior, No. 31, p. 625-654.

Kelty, C., Panofsky, A. ir kt. (2015). Seven Dimensions of Contemporary Participation Disentangled. Journal of the association for information science and technology, Vol. 66(3), p. 474-488.

Mažeikis, G. (2013). Informacinis karas dèl atviros daugialypumų bendruomenès. Agora. Politiniu komunikacijų studijos, Nr. 2, p. 7-23.

Pruskus, V. (2013). Internetinès kultūros produktų kūrimo ir teikimo etiniai aspektai. Logos, Nr. 74, p. $183-189$.

Rekis, D. (2014). Būsimuju pedagogu socialinio dalyvavimo aukštosios mokyklos gyvenime igyjiniai kaip ugdymo(si) karjerai prielaida. Daktaro disertacija. Klaipėda: KU.

Ruškus, J. (2007). Neigalumas ir socialinis dalyvavimas. Kritine patirties ir galimybiu refleksija. Šiauliai: ŠU.

Sinnreich, A. (2016). Sharing in spirit: Kopimism and the digital Eucharist. Information, Communication \& Society. Vol. 19, No. 4, p. 504-517.

\section{LITHUANIAN INTERNET SUBCULTURE BY SOCIAL PARTICIPATION ASPECT: TORRENT SITE TYPE CASE}

\section{Darius Rekis, Simona Rekienè}

\section{Summary}

It is not a novelty that the internet and new technologies and their granted possibilities make an impact for a modern society. Thanks to the internet that today we can talk about global, as well as itself internet, internet pirate subculture phenomenon which has become various research object of scientists. Internet pirates are considered copyright infringers who access their activities as the philosophy of freedom approach to all the information. Copying and distributing copyright production without the author's knowledge is considered as the crime compared to theft, so internet subculture name - pirates, is derived from it. On the specifics of this subculture all participants hide their personalities after a variety of invented names and even communicating with each other. While governments where looking to find the ways to control internet piracy activities, naturally where provoked various resistance movements for freedom approach to all the information. By negative opponents, banned "piracy" would damage human's right to information, knowledge, information owners would have to filter traffic, prohibit approaches to illegal information and the internet would lose its' freedom as encompassing whole network or limitless source of information and knowledge function.

Torrent - technological opened informative society measure or file sharing program. Torrent website is one of the internet pirate subculture examples, which has a certain organizational structure which supports the functioning of the website and users, who download and distributes a variety of files. In 2012 European 
union member states (among them and Lithuania) signed "Anti-Counterfeiting Trade Agreement" (ACTA) agreement which regulates the possibilities to track the internet users and reveal their private data without a court order, to filter the flow of information service providers, impose additional penalties including disconnection from the internet although the internet users and active pirated products distributors tries to remain unidentified. For this reason, relevant and interesting subject for research internet pirate subculture is difficult-to research using usual methods and perhaps it is the reason why in Lithuania it is still almost not studied.

Internet as an open information sharing platform besides the communication habits of society also change and form new definition of social participation opportunities. Kelty, Panofsky and others (2015) participation in digital space describes as modern but while analyzing it, authors does not propose to distinguish as a new type of participation in society, because the only difference is persons operating environment, for that scientists offers modern participation in the space of internet, analyze according to usual criteria defining social participation phenomenon. Social participation - this is the person's action in an opened society informally committing to it for mutual benefit which is materially not intangible and manifests itself in person's inner qualities that determine its potential opportunities and impact in external factors context. The personal participation in social aspect is permitted through the experience gained from social capital, knowledge, skills, selfhelp, educating individual's positive personal qualities, self-realization and so on. Benefits of person's action (not necessarily realized) is one of the main motivating factors to operate, so analyzing data by this assumption in order to identify possible persons gains permitted by social participation in internet pirate subculture.

The research object (Internet pirate torrent website subculture community of Lithuania) specifics led to use less applicable in Lithuania narrative research strategy. Like many of the qualitative research, narrative is criticized for subjectivity of data but is the method which exactly led to a deeper insight into the research object. According to I. Goodson and S. R. Gill (2011), the evaluation of narrative research should focus on how meaningful and how deep the researchers were able to reveal the individuals' experience as well as to assess whether the researcher well discerned narrative scenes and have been successful to define the main narrative themes. If these things by researcher were done well, the research has validity while if an experiences represent a wider social group it is not so important. This article attempts internet pirate subculture of Lithuania applying narrative research strategy through the social participation in the digital space prism. In order to distance from the legal assessment of the activity there are raised essential questions: what are the specifities of social participation in internet, available activity expression and potentially benefits for acting person. There are analyzed Lithuanian to- 
rrent site case to identify how the internet pirate communities involve internauts, what are motivation factors to be active in it and what are the structure and specifics of internet pirate community.

The research showed that the main motivation factors for internet pirates to involve to torrent website was the communication and recognition of the community. Community members rarely from this activity receives or expects to receive financial benefits, they are socially involved in such communities and simply letting their leisure time and communicating with peers. While Internet piracy community members can be divided into active and passive, focus in the research is on active members, those who are not just downloading files or distribute them but also supports the functioning of the site contributing themselves to make films sound recording, translation and website administration. It was found that according to the functions carried out by members they are devided in that community as: administrators, owners, interpreters, voice talents, and so on. Assessing by the aspect of social participation, active participation in these communities is good as the participation in non-governmental organizations if not assessing this participation in legal aspect or the format of communication. Social participation in the community of torrent website, makes possibilities to acquire new knowledge and develop their communication, organization, foreign language, films sound recording and other capacities, increases person's social capital, makes opportunities for self-expression and self-development. Therefore, the internet piracy subculture cannot be seen as the delinquent behavior. It is the possibility to explore the communities of the internet users assessing these different aspects and accept as a new public social participation method.

Although the data of the research can not be considered unambiguous but they allows to look at the little researched area of Lithuania from a different point, it means, not only as a criminal activity but also as a kind of social participation. Torrent websites as the activities of community are not very different from nongovernmental format of organizations and if not copyright problem probably there will be no questions it is good or bad. It was found that this community even compete with each other and has its own communication and operational support culture. Evaluating the test data it is clear that the active intervention of the community using technologies like internet, its members acquire certain competencies, expand social capital, communicate and socializes as well as in any other community, so it is important to research this area as an innovative and having an impact on our modern society. 
